Short Article

\title{
Human-Plasmodium Like in Domestic-goat Blood in Malaria Endemic Areas in Purworejo Indonesia
}

\author{
$\underline{\text { Didik Sumanto }}^{1,2}, \underline{\text { Suharyo Hadisaputro }}^{1}, \underline{\text { M Sakundarno Adi }}{ }^{3}, \underline{\text { Siti Susanti }}^{4}, \underline{\text { Sayono }}^{2}$ \\ ${ }^{1}$ Faculty of Medicine, Universitas Diponegoro Semarang, Indonesia. \\ ${ }^{2}$ Faculty of Public Health, Universitas Muhammadiyah Semarang, Indonesia. \\ ${ }^{3}$ Magister of Epidemiology, Postgraduated Universitas Diponegoro Semarang, Indonesia. \\ ${ }^{4}$ Faculty of Animal and Agriculture Science, Universitas Diponegoro Semarang, Indonesia. \\ DOI: https://doi.org/10.24321/0019.5138.202185
}

\section{I $\quad \mathbf{N} \quad \mathbf{F} \quad \mathbf{O}$}

\section{Corresponding Author:}

Didik Sumanto, Faculty of Medicine, Universitas Diponegoro Semarang, Indonesia and Faculty of Public Health, Universitas Muhammadiyah Semarang, Indonesia.

E-mail Id:

didik.24272@gmail.com

Orcid Id:

https://orcid.org/0000-0003-4714-4901

How to cite this article:

Sumanto D, Hadisaputro S, Adi MS, Susanti S, Sayono. Human-Plasmodium Like in Domesticgoat Blood in Malaria Endemic Areas in Purworejo Indonesia. J Commun Dis. 2021;53(4):148-152.

Date of Submission: 2021-10-29

Date of Acceptance: 2021-12-24

\section{$\begin{array}{llllllll}\mathbf{A} & \mathbf{B} & \mathbf{S} & \mathbf{T} & \mathbf{R} & \mathbf{A} & \mathbf{C} & \mathbf{T}\end{array}$}

Background: Etawa crossbreed goats are cultivated livestock by Jatirejo Kaligesing Purworejo villagers. This village is the area with the highest malaria incidence in the Province of Central Java in 2017. The Annual Parasitic Incidence (API) is $0.32 \%$. Verified malaria vectors are Anopheles aconitus and Anopheles maculatus. Studies show that vectors prefer goat blood over humans. The research aims to trace the presence of human-plasmodium in Etawa-goat blood.

Method: A cross-sectional study was conducted to explore the presence of $h$-Plasmodium in domestic goats' blood in pre-elimination malaria areas. 97 Etawa-goats' samples were taken by purposive sampling. Microscopic detection of human-plasmodium in Etawa-goat's blood was carried out on thick blood preparations by Giemsa staining.

Results: Human-plasmodium like was detected on four slides, with the findings of three slides resembling $P$. vivax trophozoites and one slide resembling $P$. falciparum trophozoites.

Conclusion: The presence of parasites similar to $P$. vivax and $P$. falciparum in goats' blood is important initial information to continue studies on the transmission of $h$-Plasmodium in domestic livestock. Replication studies in high case incidence areas are needed to complete the microscopic visualisation and are supported by molecular testing.

Keywords: Malaria, Human-Plasmodium like, Domestic Goat

\section{Introduction}

Malaria is a disease caused by human-Plasmodium (h-Plasmodium), transmitted by Anopheles and is one of the important infectious diseases throughout the world. Anopheles mosquito is a definitive host as well as a vector of $h$-Plasmodium parasitic spread. ${ }^{1}$ Some Anopheles species have zoophilic properties, which prefer sucking the blood of animals to that of humans. ${ }^{2}$ The zoophilic nature of Anopheles is in accordance with the fact that the presence of livestock around residential homes is one of the factors related to its role as a barrier in the transmission of malaria, ${ }^{3-5}$ although until now the real role of livestock as a barrier has not been known in detail. ${ }^{6}$

The results of blood meal tests on Anopheles aconitus from 
several locations in Central Java Province showed that 93.5\% came from animals and $6.5 \%$ from humans. Goat blood is the main source of the meal. In some locations where there are very few or no livestock at all, the human blood meal index rose to $54.3 \% .^{7}$ The number of Anopheles maculatus being caught in the garden with goat bait is higher than in settlements with human bait $(C B R=42.38 ; M B R=12.40)$. ${ }^{2}$ Anopheles mosquito population is found far more in the cage of livestock than in a room filled with humans. ${ }^{5}$

The use of livestock to divert Anopheles attacks must be far enough from the settlement so that the zoophilic Anopheles does not attack the population. ${ }^{4}$ The use of insecticide ruminants is effective to kill the mosquitoes but not effective for diverting Anopheles attacks. ${ }^{3}$ One of the invasion mechanisms of $h$-Plasmodium into human red blood cells is through glycophorin A and B receptors. ${ }^{8}$ The existence of glycophorin receptors on ruminant blood cells opens the opportunity for $h$-Plasmodium invasion of goat red blood cells in malaria-endemic areas. The similarity of glycophorin A and B receptors possessed by human red blood cells and ruminant red blood cells ${ }^{9}$ opens the chance of invasion of $h$-Plasmodium to ruminants red blood cells through zoophilic and zooanthropophilic Anopheles bites. ${ }^{2}$

Kaligesing Region Purworejo Regency, which borders Kulonprogo Regency, is in a Menoreh hilly area which is one of the malaria-endemic areas that is relatively difficult to eradicate. Until 2014, Jatirejo Village still had API values of $1.46 \% .{ }^{10}$ In 2016, Jatirejo Village succeeded in reducing it to $0.32 \% .{ }^{11}$ Kaligesing is known as an area where its people like to breed Etawa-goats. The proportion of the livestock population in Kaligesing is 54,644 Etawa crossbreed goats, 10,197 local goats, and 213 sheep. ${ }^{12}$

The existence of zooanthropophilic vectors with abundant livestock populations and in malaria-endemic areas are three things that support each other in the process of transmission and spread of malaria. Zoophilic Anopheles' bite on domestic livestock is clearly unavoidable. If Anopheles already contains $h$-Plasmodium sporozoites, the entry of parasites into the body of cattle is inevitable. The presence of glycophorin receptors on human red blood cells and ruminant animals should be taken into account in anticipation of the development of $h$-Plasmodium in livestock bodies, ${ }^{9}$ although humans and livestock certainly have different physiological conditions and immune responses. It is very interesting to start developing hypotheses regarding the ability of $h$-Plasmodium to breed in livestock bodies by initially detecting parasites in animal blood in malaria-endemic areas.

\section{Material and Method}

The study design was cross-sectional. Samples of Etawagoats around the homes of malaria-positive sufferers within a radius of $100 \mathrm{~m}$ in Jatirejo Village, Kaligesing Purworejo were collected. A total of 97 Etawa-goats were taken by purposive sampling technique from 25 cages. Collection of blood specimens of the Etawa crossbred goats was carried out in July 2018. A thick blood smear was made on each ${ }^{13}$ and stained with Giemsa 1:20 for 45 minutes. Detection of h-Plasmodium in goat blood was carried out microscopically. The specified inclusion criteria were that Etawa-goats are within a maximum radius of 100 meters from the place where malaria sufferers live, that goats are 3 months old and have been in the study site for at least the last 3 months. The test was carried out in the Laboratory of Epidemiology and Tropical Diseases, University of Muhammadiyah Semarang. The research ethics certificate was issued by the Health Research Ethics Commission, Faculty of Public Health, Universitas Muhammadiyah Semarang.

\section{Results}

Microscopic testing results on 97 goat blood preparations found parasites with a morphology resembling $h$-Plasmodium on four slides of thick blood (Table 1). The parasitic morphology of the subsequent findings was compared with reference morphology to confirm the findings. Microscopic findings showed clear and specific parasitic morphology of three slides resembling Plasmodium vivax (P. vivax) species and one slide resembling Plasmodium falciparum (P. falciparum). The stages found in P. vivax like are early-stage trophozoites, developmental trophozoites and the final stage of trophozoites (Figures 1, 2, and 3). P. falciparum like (Figure 4) can only be found in one form, namely the initial stage trophozoite which is in the form of a typical comma with a relatively small round nucleus and a very thin cytoplasm.

Table I.Microscopic Detection of Thick Blood Smear

\begin{tabular}{|c|c|c|}
\hline Parasite & Number (Slide) & Percentage (\%) \\
\hline P. falciparum like & 1 & 3.1 \\
\hline P. vivax like & 3 & 95.9 \\
\hline No parasites & 93 & 100 \\
\hline Total & 97 & \\
\hline
\end{tabular}




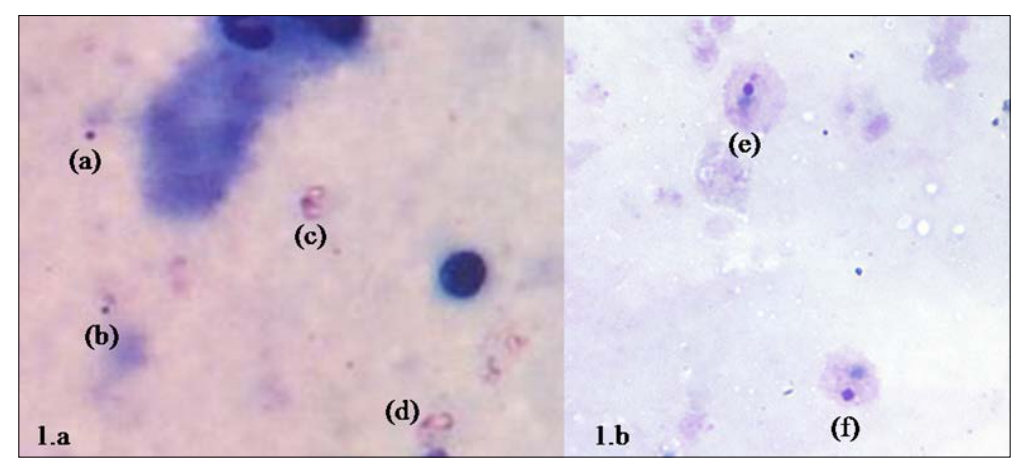

Figure I.Tropozoite Stage of $P$. vivax like ( Ia) compared with Reference (Ib) $)^{14}$

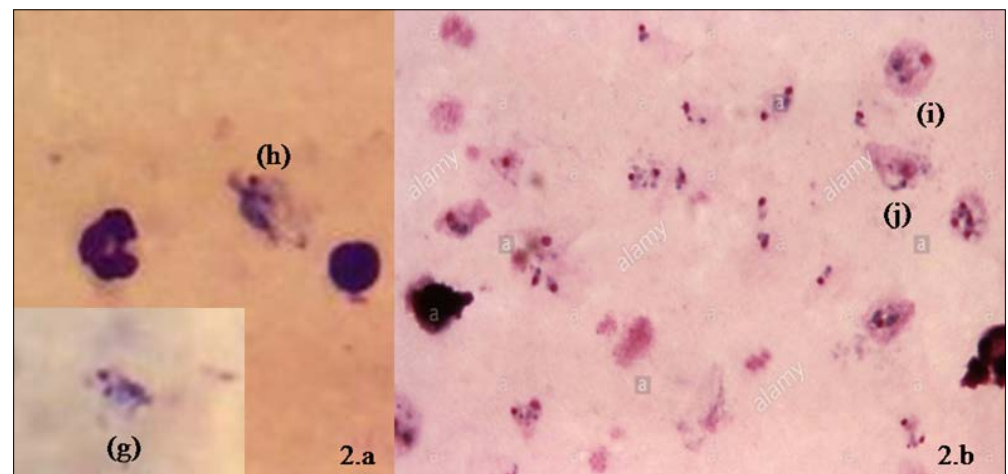

Figure 2.Tropozoite Stage of $P$. vivax like (2a) compared with Reference (2b) ${ }^{20}$

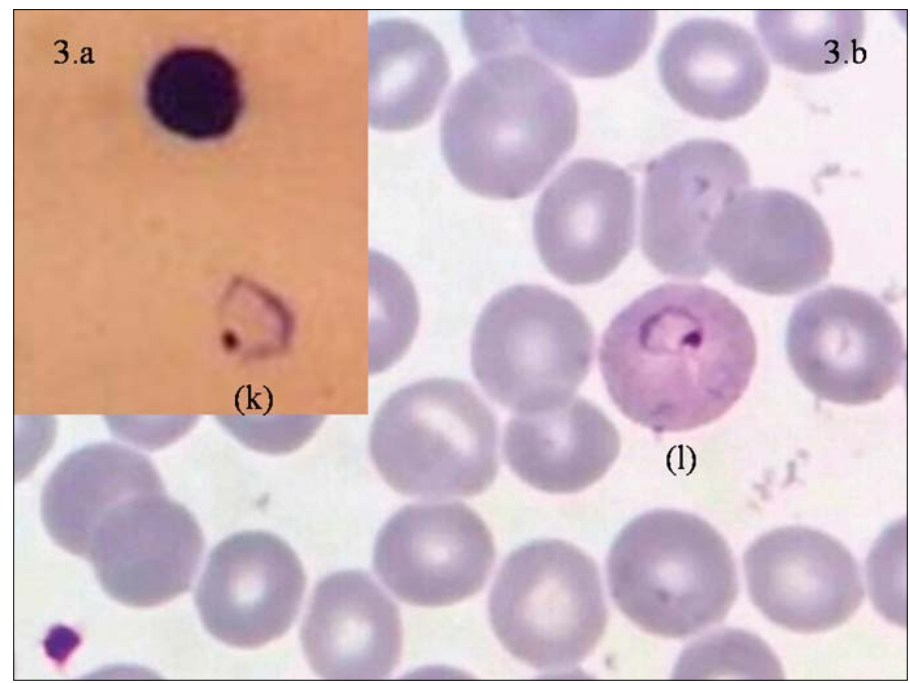

Figure 3.Tropozoite Stage of $P$. vivax like (3a) compared to Reference (3b) ${ }^{25}$

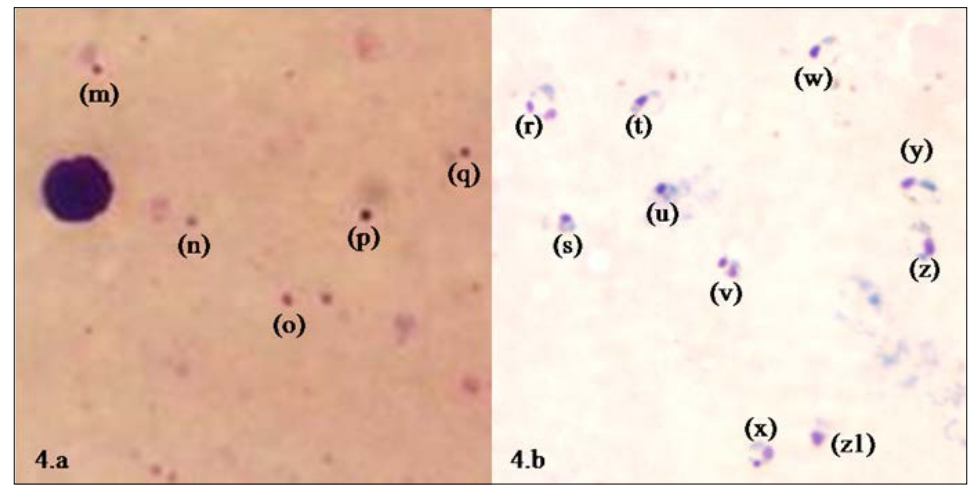

Figure 4.Tropozoite Stage of $P$. falciparum like (4a) compared with Reference (4b) ${ }^{23}$ 


\section{Discussion}

The parasite morphology in the first blood slide shows the ring-shaped trophozoite stage of $P$. vivax. Morphological findings indicate the initial ring shape $(a, b)$ and developmental shape (c,d). This form has a characteristic, one red core. There is a similarity in the shape and colour of parasitic nuclei morphology of the findings and references..$^{14}$ In the cytoplasm section, the findings show two different stages of development in which the cytoplasm only looks a little like eyebrow hair $(a, b)$ similar to the shape of the reference morphology (e,f). The only difference is in the red zone ${ }^{15,16}$ which is not apparent in the area of parasitic finding. It is not as clear as the morphology of the reference. Meanwhile, the parasitic morphology found in the developmental stage (c,d) showed a cytoplasm morphology with a clearer ring shape. The cytoplasm is very clear on the right and left sides of the parasitic nucleus and forms a ring but the shape is not smooth, resembling the typical ring shape of $P$. vivax. This shape is similar to the reference morphology in Figure 2(b).

On Giemsa-stained blood smears, RBCs infected with $P$. vivax will appear larger than uninfected cells. ${ }^{17}$ Trophozoite may appear as thick, large ameboid rings. The diameter of parasites is about one half the RBC. ${ }^{18}$ Schuffner's dots are present around the parasites. ${ }^{19}$ The parasites found on the two slides of samples $(\mathrm{g}, \mathrm{h})$ closely resemble the trophozoite stage of $P$. vivax of reference $(\mathrm{i}, \mathrm{j}) .{ }^{20}$ The parasitic nucleus is relatively reddish in colour, very similar to the reference image. The parasitic cytoplasm of the dark purple findings appearing irregular in shape also bears a resemblance to the reference image. This cytoplasm shows that the trophozoite stage is advanced, not much different from the morphology of the reference image. ${ }^{20}$ Schuffner spots ${ }^{15,16}$ in the parasitic findings are not so obvious. The red zone is not as clear as the reference image, but there is still a reddish tinge around the parasitic cytoplasm (Figure 2).

The parasitic morphology of the third finding is a real ameboid ring $(k)$ with a relatively large reddish round nucleus and intact non-smooth ring-shaped cytoplasm. Compared with reference morphology $(\mathrm{I}),{ }^{21}$ it is almost no different. Unfortunately, no reference morphology was found on the same type of slides. The parasitic findings were from thick drops while the reference morphology was from a thin blood smear. The difference between the two lies in the morphology of the red blood cells that are still intact in the reference morphology, while in the parasite, the discovery of red blood cells is not visible because they have been haemolysed..$^{15}$ The enlargement of red blood cells in P. vivax infection ${ }^{16,22}$ is not that apparent in the thick blood slide, however, relative comparison with adjacent white blood cells shows that the infected red blood cells are already enlarged (Figure 3).

The next parasite found on the fourth slide showed a morphology resembling the early stages of $P$. falciparum trophozoite. The parasitic morphology of the findings showed a round nucleus with a comma-shaped cytoplasm $(m, p, q)$ similar to the reference morphology $(g, u, v, w) .^{23}$ Another finding is that the parasite nucleus has a point shape only $(n, 0)$ similar to the reference morphology $(z 1)$ (Figure 4). Both forms of morphology are typical forms of $P$. falciparum trophozoite stage, the earliest stage in the thick blood, which is shaped like a dot, comma, exclamation mark and an incomplete ring resembling the wings of a flying bird. ${ }^{15}$ In the initial stages, the shape of the trophozoite ring stage in the middle of the parasite is quite thin while the edge is relatively thicker which contains the nucleus and other organelles. ${ }^{16,24}$ This causes the shape of the parasite to look like a ring in a Giemsa staining. The shape of this ring is part of the development of the parasitic trophozoite stage. Morphologically, the typical ring shape and number of rings can provide more information about the infection that occurs. ${ }^{25}$

\section{Conclusion}

The findings of parasites in goat's blood being similar to $P$. vivax and $P$. falciparum are important early information. A similar study in malaria-endemic areas with high levels of parasitemia is needed to visualise parasite morphology on thin blood smears more clearly. Molecular detection must be done to complete these findings to reveal whether there is a transmission route of $h$-Plasmodium in domestic livestock populations.

\section{Acknowledgement}

The best award was given to the Village Malaria interpreters at the Kaligesing Health Center who had assisted in specimen collection, the Purworejo District Health Office who provided a research permit and the Health Research Ethics Commission of the Faculty of Public Health, Universitas Muhammadiyah Semarang, who had reviewed and approved the research ethics.

\section{Source of Funding}

There are no funders in this research.

\section{Conflict of Interests: None}

\section{References}

1. Harijanto P, Laihad F, Poesporodjo J. Epidemiologi Malaria di Indonesia [Internet]. Buletin Jendela Data dan Informasi Kesehatan, Kementerian Kesehatan Rl; 2011 [cited 2021 Jan 20]. Available from: https://pusdatin. kemkes.go.id/download.php?file=download/pusdatin/ buletin/buletin-malaria.pdf. Indonesian.

2. Shinta, Sukowati S, Pradana A, Marjianto, Marjana P. Beberapa Aspek Perilaku Anopheles maculatus Theobald di Pituruh, Kabupaten Purworejo, Jawa Tengah. Bul Penelit Kesehat [Internet]. 2013 [cited 
2021 Jan 20];41(3):131-41. Available from: http:// ejournal.litbang.depkes.go.id/index.php/BPK/article/ view/3284/3278. Indonesian.

3. Hanafy I, Soviana S, Hadi UK. Keanekaragaman Jenis, Kepadatan Dan Aktivitas Menghisap Darah Anopheles (Diptera: Culicidae) Pada Aplikasi Zooprofilaksis Di Daerah Endemis Malaria [Internet]. Sekolah Pascasarjana Institut Pertanian Bogor; 2015 [cited 2021 Jan 20]. Available from: https://repository.ipb.ac.id/ handle/123456789/77542. Indonesian.

4. Donnelly B, Berrang-Ford L, Ross NA, Michel P. A systematic, realist review of zooprophylaxis for malaria control. Malar J. 2015 Aug;14(1):313. [PubMed] [Google Scholar]

5. Yakubu A, Singh A. Livestock : An alternative mosquito control measure. Sokoto J Vet Sci. 2008;7(1). [Google Scholar]

6. Hurd H. Can cows protect against mosquito bites ? [Internet]. Biomed Central Blogs; 2014 [cited 2014 Mar 27]. Available from: http://blogs.biomedcentral. com/bugbitten/2014/03/27/can-cows-protect-againstmosquito-bites-2/

7. Kirnowardoyo S. Status of Anopheles malaria vectors in Indonesia. Southeast Asian J Trop Med Public Health. 1985 Mar;1:129-32. [PubMed] [Google Scholar]

8. Cowman AF, Healer J, Marapana D, Marsh K. Review malaria: biology and disease. Cell. 2016 Oct;167(3):61024. [PubMed] [Google Scholar]

9. Lobo C. Babesia divergens and plasmodium falciparum use common receptors, glycophorins $A$ and $B$, to invade the human red blood cell. 2005 Jan;73(1):649-51. [PubMed] [Google Scholar]

10. Dinas Kesehatan Kab [Internet]. Puworejo. Profil Kesehatan: Dinas Kesehatan Kabupaten Purworejo. Purworejo; 2015 [cited 2021 Jan 21]. Available from: https://docplayer.info/70633864-Profil-kesehatan-2015. html. Indonesian.

11. Dinas Kesehatan Purworejo [Internet]. Angka Kasus Malaria. Purworejo; 2016 [cited 2021 Jan 21]. Available from: https://www.who.int/indonesia/purworejoeliminasi-malaria. Indonesian.

12. Purworejo BPS [Internet]. Populasi Ternak Menurut Kecamatan di Kabupaten Purworejo; [cited 2021 Jan 21]. Available from: https://purworejokab.bps.go.id/ statictable/2015/05/21/18/populasi-ternak-menurutkecamatan-di-kabupaten-purworejo-tahun-2013.html. Indonesian.

13. Mathison BA, Pritt BS. Update on malaria diagnostics and test utilization. J Clin Microbiol. 2017 Jul;55(7):200917. [PubMed] [Google Scholar]

14. mcdinternational.org [Internet]. Diagnostic Finding Malaria: Ring-form trophozoites in a thick blood smear; 2011 [cited 2019 Aug 19. Available from: https://www. mcdinternational.org/trainings/malaria/english/ DPDx5/HTML/Frames/M-R/Malaria/vivax/body_ malariadfvivring

15. Chiodini P, Moody A, Manser D. Atlas of medical helminthology and protozoology. 4th ed. Horne T, editor. London: Churchill Livingstone; 2001. p. 61-9. [Google Scholar]

16. Mahmud R, Lim YA, Amir A. Medical parasitology. Cham, Switzerland: Springer International Publishing; 2017. 40 p. [Google Scholar]

17. Adams JH, Mueller I. The biology of plasmodium vivax. Cold Spring Harb Perspect Med. 2017;7(9). [PubMed] [Google Scholar]

18. Menkin-Smith L, Winders W. Malaria (Plasmodium Vivax) [Internet]. In: StatPearls. Treasure Island (FL): StatPearls Publishing; 2019 [cited 2019 May 4]. Available from: https://www.ncbi.nlm.nih.gov/books/NBK538333/. [Google Scholar]

19. CDC. Laboratory Diagnosis of Plasmodium vivax [Internet]. Centre for Diseases Controle and Prevention; 2017 [cited 2021 Jan 21]. p. 1-4. Available from: https:// www.cdc.gov/dpdx/resources/pdf/benchAids/malaria/ Pvivax_benchaidV2.pdf

20. Melvin M. Photomicrograph of the malaria causing parasite Plasmodium vivax, in ring and young trophozoite forms, on a thick film blood smear with Giemsa stain [Internet]. Alamy's library from CDC; 1971 [cited 2019 Aug 19]. Available from: https://www.alamy.com/ stock-photo-photomicrograph-of-the-malaria-causingparasite-plasmodium-vivax-in-173101553.html

21. Keas BE. Microscopy - Plasmodium species [Internet]. Michigan State University; 1999 [cited 2021 Jan 21]. Available from: https://msu.edu/course/zol/316/ psppscope.html

22. CDC [Internet]. Ring-form trophozoites of P. vivax in thick and thin blood smears. U.S. Department of Health \& Human Services; 2017 [cited 2019 Aug 19]. Available from: https://www.cdc.gov/dpdx/malaria/index.html

23. Image Library [Internet]. Plasmodium falciparum: Ring form trophozoites in thick blood smears (Image Library Malaria); 2009 [cited 2019 Aug 17]. Available from: https://mcdinternational.org/trainings/malaria/english/ dpdx5/html/ImageLibrary/M-R/Malaria/falciparum/ body_Malaria_falciparum_il4

24. Bannister LH, Hopkins JM, Fowler RE, Krishna S, Mitchell $\mathrm{GH}$. A brief illustrated guide to the ultrastructure of Plasmodium falciparum asexual blood stages. Parasitol Today. 2000 Oct;16:427-33. [PubMed] [Google Scholar]

25. Balestra B, Carnino L. In vitro exflagellation of Plasmodium vivax. New Engl J Med. 2016;375(12):e27. [Google Scholar] 